\title{
Concurrent granulomatous polyangiitis and squamous cell carcinoma of the lung: a case of balancing treatment
}

\author{
Duncan Alston, ${ }^{1}$ Ravi Rajakariar, ${ }^{2}$ Michael Sheaff, ${ }^{3}$ Nick Lever ${ }^{1}$
}

${ }^{1}$ Department of Renal Medicine, Barking Havering and Redbridge University Hospitals NHS Trust, Romford, UK

${ }^{2}$ Department of Renal

Medicine, Barts and The Royal London Hospital, London, UK ${ }^{3}$ Department of Histopathology, Barts and The Royal London Hospital, London, UK

\section{Correspondence to}

Dr Duncan Alston,

dsalston@gmail.com

Accepted 29 March 2016

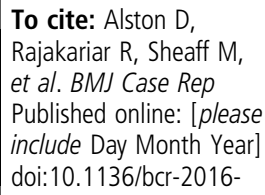

\section{DESCRIPTION}

Granulomatous polyangiitis (GPA) is a rare smallvessel vasculitis characterised by lesions in the upper respiratory tract, lungs and kidneys.

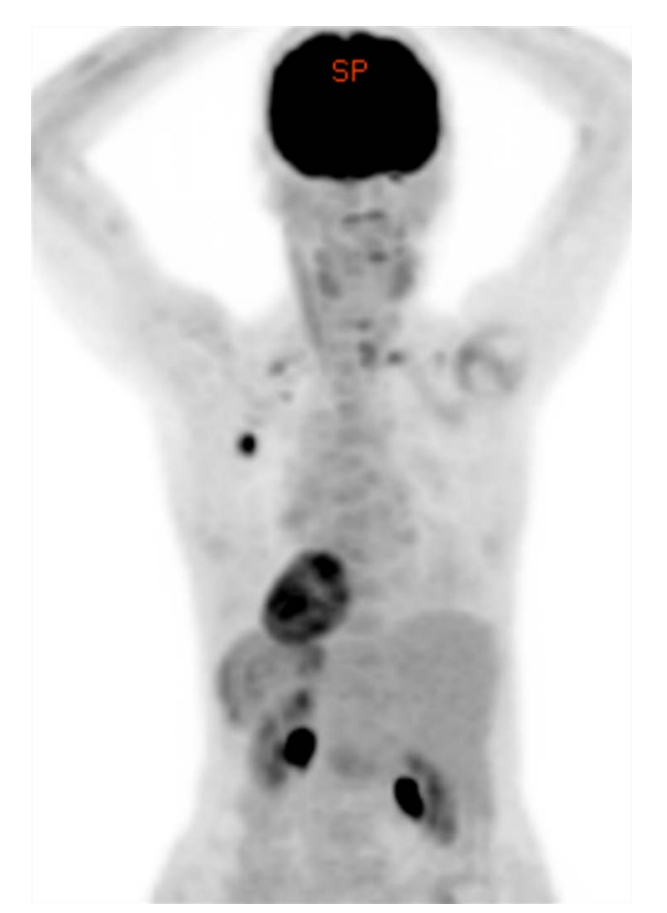

Figure 1 PET scan showing an active lung nodule. PET, positron emission tomography.
Diagnosis of lung lesions can be difficult and misdiagnosis as lung cancer is not uncommon. ${ }^{1}$ Aggressive, long-term immunosuppression with drugs such as cyclophosphamide is necessary to prevent lung disease and development of end-stage renal failure.

We describe a case of a 79-year-old woman with a history of previous breast malignancy who presented with a 6-month history of weight loss and cough. She was found to have multiple lung nodules, which, after a period of active monitoring, began to increase in size. A positron emission tomography scan identified one metabolically active nodule in the left upper lobe (figure 1), which was removed by a video-assisted thoracoscopic surgery wedge resection. Histology showed a squamous cell carcinoma as well as necrotising granulomatous vasculitis, suggestive of GPA (figure 2). Shortly after this the patient presented with deteriorating renal function. She had an active urinary sediment and a positive proteinase 3 (PR3) antibody titre of $91 \mathrm{U} /$ $\mathrm{mL}$. A renal biopsy showed necrotising crescentic glomerulonephritis in keeping with an antineutrophil cytoplasmic antibody positive pauci-immune vasculitis: namely, GPA. She was pulsed with methylprednisolone and then maintained with $60 \mathrm{mg}$ prednisolone daily. This posed a therapeutic dilemma as immunosuppression with cyclophosphamide has been associated with recurrence of malignancy. ${ }^{2}$ Consequently, seven sessions of plasma exchange were successfully used to reduce her PR3 titre to $5.4 \mathrm{U} / \mathrm{mL}$. Unfortunately, the patient's renal function continued to deteriorate.
CrossMark

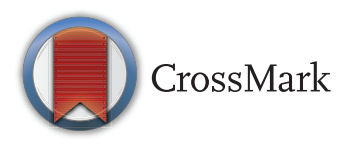

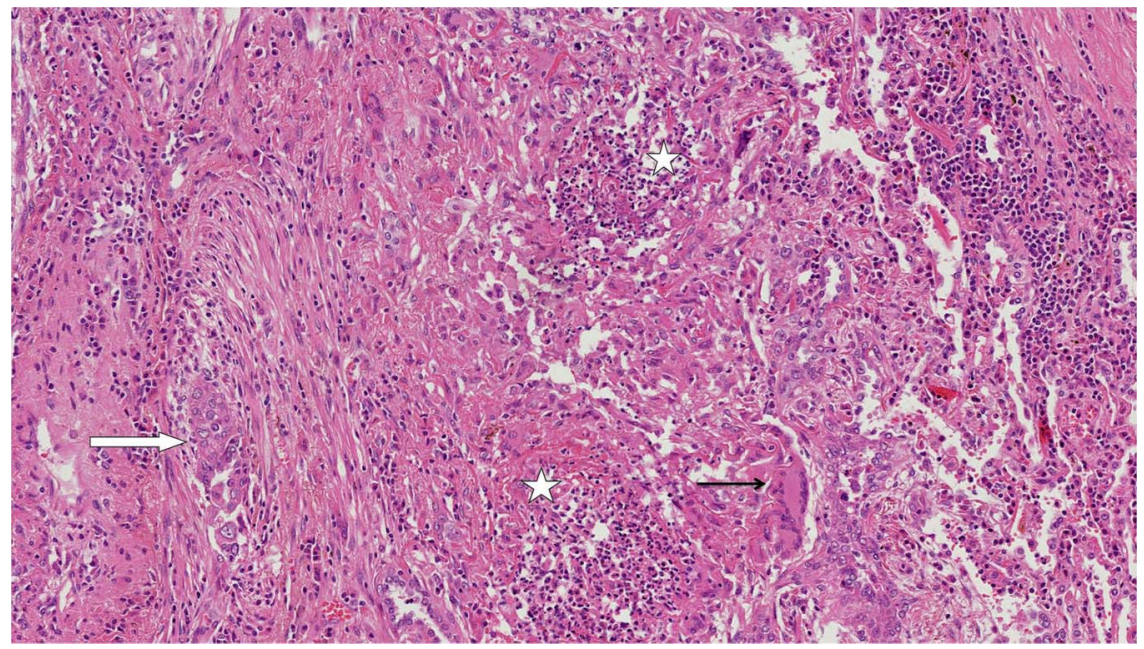

Figure 2 Lung resection showing both GPA (necrosis, stars and giant cell, thin arrow) and invasive island of squamous cell carcinoma (thick arrow). GPA, granulomatous polyangiitis. 
Renal replacement therapy was discussed, but the patient declined.

\section{Learning points}

- It is important to keep an open mind to rare causes of a lung lesion.

- Immunosuppression in patients with recent malignancies is complex and requires careful balancing of treatment priorities.
Contributors DA prepared the manuscript with help from all the other authors. RR was in charge of the patient's care at the Royal London Hospital. MS analysed and prepared the histology. NL was the consultant in charge of the patient's care.

Competing interests None declared.

Patient consent Obtained.

Provenance and peer review Not commissioned; externally peer reviewed.

\section{REFERENCES}

1 Williamson JD, Murphree SS, Wills-Frank L. Atypical squamous cells as a diagnostic pitfall in pulmonary Wegener's granulomatosis. A case report. Acta Cytol 2002;46:571-6.

2 Travis LB, Gospodarowicz M, Curtis RE, et al. Lung cancer following chemotherapy and radiotherapy for Hodgkin's disease. J Natl Cancer Inst 2002;94:182-92.

Copyright 2016 BMJ Publishing Group. All rights reserved. For permission to reuse any of this content visit http://group.bmj.com/group/rights-licensing/permissions.

BMJ Case Report Fellows may re-use this article for personal use and teaching without any further permission.

Become a Fellow of BMJ Case Reports today and you can:

- Submit as many cases as you like

- Enjoy fast sympathetic peer review and rapid publication of accepted articles

- Access all the published articles

- Re-use any of the published material for personal use and teaching without further permission

For information on Institutional Fellowships contact consortiasales@bmjgroup.com

Visit casereports.bmj.com for more articles like this and to become a Fellow 